\title{
Penyuluhan Literasi Pajak Berbasis Komunikasi Publik di PT ZAF Internasional
}

\author{
Ai Annisaa Utami, Khoirul Umam*, Tjipto Djuhartono \\ Universitas Indraprasta PGRI \\ *khoirulumam77@yahoo.com
}

\begin{abstract}
Abstrak
Arah dan fokus pelaksanaan pengabdian masyarakat ini adalah menciptakan literasi pajak untuk UMKM di ZAF Internasional. Literasi pajak dikembangkan dalam peraturan dalam proses pembayaran, pemungutan, pemotongan, dan pelaporan pajak untuk UMKM. Ruang lingkup pengetahuan dan peraturan terkait pajak UMKM harus dipahami secara menyeluruh oleh wajib pajak pemilik UMKM. Mengingat pajak UMKM merupakan jenis pajak yang pemungutannya merupakan self assessment di mana setiap informasi untuk pembayaran dan pelaporan dilakukan secara mandiri oleh wajib pajak UMKM yang bersangkutan. Metode yang digunakan adalah wawancara berupa tanya jawab dengan audience, observasi, dan penyuluhan materi pajak UMKM. Mitra utama dalam kegiatan pengabdian masyarakat ini adalah PT ZAF Internasional yang terletak di Depok dengan komposisi peserta meliputi karyawan bagian keuangan, bagian pajak, serta pemilik PT ZAF Internasional. Berdasarkan penyuluhan yang telah dilaksanakan hasil yang tampak adalah penggunaan PPH Final untuk UMKM yang tertuang dalam PP Nomor 23 Tahun 2018 dengan perubahan tarif sebesar 0,5\%.
\end{abstract}

Kata Kunci: UMKM, komunikasi publik, pajak

\section{Public Communication-Based Tax Literacy Counseling at PT ZAF Internasional}

\begin{abstract}
The direction and focus of this community service implementation is to create tax literacy for MSMEs at ZAF International. The tax literacy developed is in the form of regulations in the payment process, collection, deduction, and tax reporting for MSMEs. The scope of knowledge and regulations related to MSME taxes must be comprehensively understood by the taxpayers of MSME owners. Considering that MSME tax is a type of tax whose collection is a self-assessment where all information for payment and reporting is carried out independently by the concerned UMKM taxpayer. The method used during the community service process is interviews in the form of questions and answers with the audience, observation, and counseling on MSME tax material. The main partner in this community service activity is PT ZAF International which is located in Depok with a composition of participants including employees of the finance division, tax department, and owners of PT ZAF Internasional. Based on the counseling that has been implemented, the visible results are the use of Final PPH for MSMEs as stated in PP Number 23 of 2018 with a change in rates of $0.5 \%$.
\end{abstract}

Keywords: SME, public communication, tax

\section{PENDAHULUAN}

Literasi perpajakan untuk UMKM saat ini menjadi masalah utama bagi wajib pajak pemilik UMKM. Sebagian besar UMKM saat ini belum memahami proses dan alur yang sesuai dalam memenuhi kewajibannya untuk melakukan pembayaran dan pelaporan pajak. Padahal menurut penelitian yang dilakukan (Sari, 2019) menyatakan bahwa literasi pajak dan sanksi pajak berpengaruh terhadap kepatuhan wajib pajak UMKM. Urgensi penyuluhan ini adalah memberikan kontribusi yang nyata bagi para pelaku bisnis lingkup UMKM untuk memahami pajak final sehingga berujung pada kepatuhan pajak sesuai dengan harapan Pemerintah. Penerimaan pajak dari sektor UMKM belum maksimal, hal ini tercermin dari proporsi tingkat kepatuhan pajak pemilik UMKM yang hanya 2,2\% dari total keseluruhan penerimaan pajak secara Nasional. 
Dalam penelitian yang dilakukan oleh Mangoting dan Sadjiarto (2013) menjelaskan bahwa kepatuhan pajak seorang wajib pajak sangat dipengaruhi oleh faktor internal dan faktor eksternal. Faktor internal merupakan sejumlah faktor yang berasal dari dalam diri wajib pajak sendiri serta berhubungan dengan berbagai karakteristik individu yang menjadi faktor pemicu dalam melakukan kewajiban perpajakannya misalnya literasi pajak yang meliputi kemampuan kognisi dan pengetahuan wajib pajak terkait dengan aturan dan Undang-Undang yang mengatur tata cara perpajakan secara rinci. Sedangkan faktor eksternal yang mempengaruhi kepatuhan pajak seorang wajib pajak merupakan faktor yang berasal dari luar diri wajib pajak, misalnya situasi dan lingkungan di sekitar wajib pajak. Berdasarkan informasi ini pemahaman yang totalitas terkait dengan literasi pajak sangat dibutuhkan hal ini senada dengan informasi yang digali dari penelitian tersebut. Hal ini yang mendasari perlu dilakukan penyuluhan literasi pajak untuk mitra karena membantu mendukung pemerintah dalam meningkatkan kepatuhan wajib pajak yang berdampak pada optimalisasi penerimaan pendapatan Negara dari sektor pajak.

Beberapa upaya yang dilakukan pemerintah untuk meningkatkan kepatuhan wajib pajak UMKM adalah melalui penurunan tarif yang dipungut yaitu sebesar 0,5\%. Munculnya (PP Nomor 23 Tahun 2018 Tentang Penghasilan Atas Penghasilan Dari Usaha Yang Diterima Atau Diperoleh Wajib Pajak Yang Memiliki Peredaran Bruto Tertentu, 2018) menjadi bukti bahwa Pemerintah serius dalam mendorong kenaikan penerimaan pajak dari sektor UMKM. Kendala di lapangan ternyata cukup rumit, masalah kepatuhan pajak UMKM tidak seimbang dengan kemampuan literasi pajak bagi UMKM tersebut. (Yuliati \& Fauzi, 2020) mengungkapkan bahwa munculnya kepatuhan pajak dari para pelaku UMKM sangat didominasi oleh kemampuan mereka dalam literasi pajak. Hal ini senada dengan pernyataan (Anggraeni, 2016) mengenai kemampuan literasi dalam keuangan akan mempengaruhi proses berpikir dan cara pandang seseorang terhadap kondisi keuangan serta akan mempengaruhi perilaku pengambilan keputusan yang strategis dalam hal keuangan dan pengelolaan yang lebih baik untuk kepentingan perusahaan.

UMKM yang menjadi mitra dalam penyuluhan literasi pajak ini adalah PT ZAF Internasional. Selama berdiri PT ZAF Internasional banyak berkontribusi dalam bidang pelatihan dan pendidikan terutama yang berhubungan dengan perpajakan. Klien PT ZAF sebagian besar adalah UMKM yang difasilitasi dan dimediasi terkait dengan proses pencatatan, pembukuan, pembayaran dan pelaporan pajak. Penyuluhan ini berbentuk TOT (training for trainer) yang dilakukan kepada para karyawan PT ZAF bagian keuangan, bagian perpajakan dan pemilik perusahaan secara langsung. Pelaku bisnis di ZAF Internasional berhubungan dan bersinggungan langsung dengan klien UMKM, sehingga harapannya materi penyuluhan tentang literasi pajak UMKM bisa disampaikan secara langsung kepada wajib pajak yang bersangkutan. (Aribawa, 2016) secara general mengungkapkan bahwa implikasi dari literasi keuangan yang baik diharapkan UMKM akan mampu membuat keputusan manajemen dan keuangan yang tepat untuk peningkatan kinerja dan keberlanjutan usaha, terutama untuk meningkatkan komitmen dan kepatuhan pajak. Dari beberapa dukungan hasil penelitian ini mengungkapkan bahwa urgensi terkait dengan literasi pajak tidak bisa dipandang sebagai kebutuhan sekunder, akan tetapi menjadi kebutuhan dasar untuk fondasi kepatuhan pajak pelaku UMKM. 
Vol. 2, No. 2,

July, 2021,

pp. $77-85$

e-ISSN:

2722-2004

\section{Public}

Communication

-Based Tax

Literacy

Counseling at

\section{PT ZAF}

Internasional

A. A. Utami,

K. Umam,

T. Djuhartono

\section{METODE PELAKSANAAN}

Selama proses penyuluhan, mitra menunjukkan antusias yang tinggi. Hal ini terbukti pada setiap tahap pelaksanaan KPI (key performance index) dari peserta semakin baik, mulai dari tahap awal hingga tahap akhir penyuluhan. Adapun tahapan proses penyuluhan adalah sebagai berikut:

\section{Tahap 1 (Tahap awal)}

Tahap pertama yang dilakukan oleh tim pengabdian masyarakat adalah melakukan identifikasi kebutuhan literasi pajak klien yang sering difasilitasi oleh PT ZAF Internasional. Bagian ini dilakukan dengan melakukan wawancara dengan petugas di ZAF bagian HRD. Hasil serta output dari tahap ini adalah kebutuhan utama literasi pajak UMKM klien PT ZAF adalah prosedur pajak restoran untuk setiap transaksi ekonomi yang sesuai dengan aturan dan undangundang perpajakan.

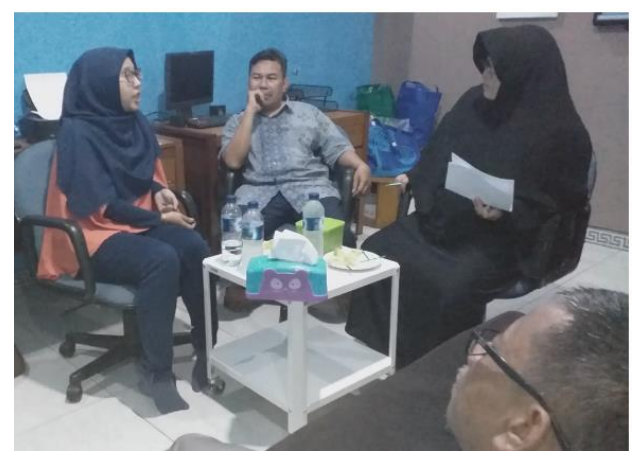

Gambar 1. Identifikasi Kebutuhan Mitra

\section{Tahap 2 (Tahap Pelaksanaan)}

Prosedur pemungutan, penyetoran, dan pelaporan pajak restoran merupakan siklus yang berulang setiap periodenya, berdasarkan pertimbangan ini maka proses pelaksanaan Pengabdian Masyarakat ini adalah sebagai berikut:

1. Pemberian Materi bagian pemungutan yaitu sebagai berikut
a. Pemahaman terkait dengan tarif
b. Mampu menghitung total omzet sebagai dasar pengenaan pajak (DPP)

2. Pemberian materi untuk bagian penyetoran
a. Tempat setoran terbaik
b. Form dan formulir untuk setoran dalam bentuk SSP

3. Pemberian materi bagian pelaporan
a. Tenggang waktu pelaporan
b. Tempat pelaporan
c. Nominal pelaporan
d. Denda dan sanksi ketika terlambat melaporkan. 


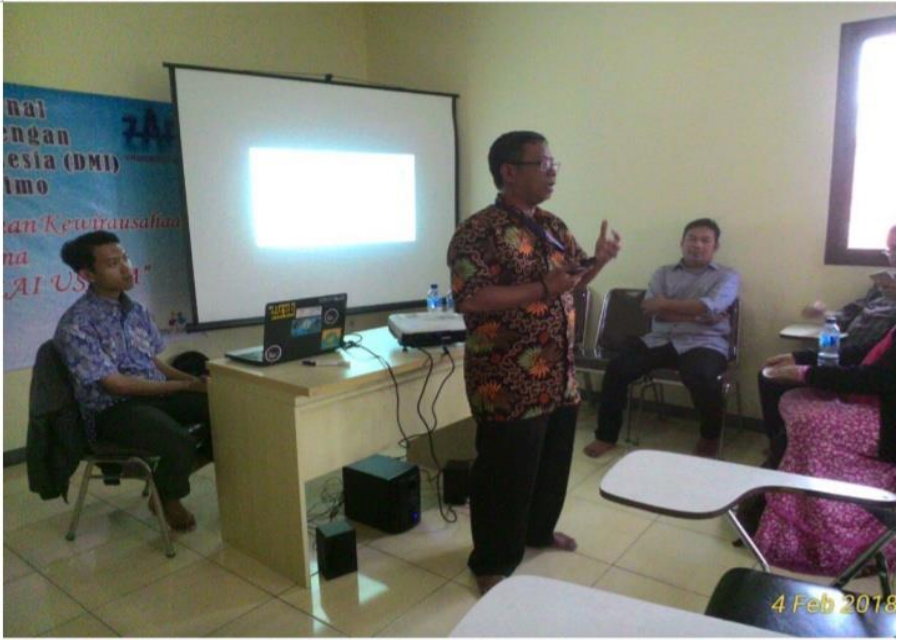

Gambar 2. Proses Penyuluhan
KANGMAS is a journal published by Neolectura, issued three times in one year. KANGMAS is a scientific publication media in the form of conceptual paper and field research related to social service work. It is hoped that KANGMAS can become a media for academics and researchers to publish their social service work and become a reference source for the development of social and humanity.

\section{Tahap 3 (Tahap Evaluasi)}

Tahap ini dilakukan sebagai bentuk monitoring oleh tim pengabdian masyarakat kepada mitra dengan cara menghitung jumlah persentase dari seluruh peserta berdasarkan kategori sangat lemah, lemah, baik, sangat baik, dan mahir. Hal ini dilakukan untuk mengukur tingkat keberhasilan pelaksanaan program pengabdian kepada masyarakat ini, apabila persentase jumlah peserta yang baik dan mahir lebih banyak maka pembinaan selanjutnya mengenai managerial skill mengelola usaha akan dilanjutkan ke jenjang yang lebih rumit, sebaliknya jika persentase peserta yang lemah dan sangat lemah dominan perlu dikaji ulang lebih lanjut dalam menentukan lokasi dan peserta. Alternatif lain yang dapat dilakukan jika presentasi peserta yang mahir dan baik rendah dilakukan dengan memperbaiki sistem pembelajaran.

Materi literasi pajak yang diberikan meliputi hal-hal di bawah ini

1. NPWP Pelaku Usaha

2. Pencatatan Transaksi dan Aktivitas Harian

3. Bentuk Bisnis Kuliner

4. Pajak Restoran

5. PPh Final UMKM

6. $\mathrm{PPh}$ Tarif Umum

7. Pemotongan PPh atas transaksi kepada Pihak Lain

8. Laporan Keuangan dan SPT Tahunan PPh

9. Pajak Pertambahan Nilai

Dari penyuluhan dan workshop ini, peserta sudah dapat mengerti dan memahami serta mulai mempraktikkan secara mandiri dalam pendaftaran dan input data pajaknya sendiri. Hal ini menjadi sesuatu yang berguna bagi mitra kami. Adapun hasil evaluasi tersebut adalah:

1. Peserta mengerti apa itu pajak UMKM untuk restoran

2. Peserta mengerti dan memahami tentang bagaimana mendaftarkan data diri dan membuat laporan keuangan dan pajaknya secara mandiri

3. Peserta mengerti jenis-jenis tarif pajak khususnya pajak untuk UMKM yang berbentuk restoran

Sudah mulai tumbuh kesadaran pada diri peserta bahwa membayar pajak bukan hanya sekedar kewajiban, tapi juga dapat menyejahterakan ekonomi bangsa ini secara keseluruhan. 
Vol. 2, No. 2,

July, 2021,

pp. $77-85$

e-ISSN:

2722-2004

\section{Public}

Communication

-Based Tax

Literacy

Counseling at

PT ZAF

Internasional

A. A. Utami,

K. Umam,

T. Djuhartono

\section{HASIL DAN PEMBAHASAN}

Pelaksanaan dan workshop peningkatan literasi pajak UMKM melalui workshop berbasis komunikasi publik di PT ZAF Internasional sebagai upaya untuk memotivasi dan membuka wawasan mengenai pengetahuan pajak dan UMKM bersama dengan sesama peserta. Kebutuhan literasi pajak untuk UMKM dimodifikasi sesuai dengan permintaan klien yaitu pajak restoran. Sebetulnya tidak ada perbedaan signifikan antara pajak UMKM restoran, jasa, maupun perusahaan dagang lainnya. Di bagian awal proses pengabdian masyarakat dilakukan wawancara dan observasi kebutuhan literasi pajak untuk para klien apakah pajak UMKM untuk perusahaan dagang, perusahaan jasa, atau restoran. Wawancara dilakukan pada tiga bagian yaitu bagian keuangan yang memiliki jobdesk untuk mencatat transaksi keuangan klien mulai dari pembukuan dan laporan keuangan, bagian kedua yang diwawancara adalah karyawan PT ZAF bidang Pajak yang memiliki jobdesk menghitung nilai pajak terutang bagi klien dan membuat rekonsiliasi laporan keuangan komersial menjadi laporan keuangan fiskal yang berbasis Undang-Undang. Terakhir tim yang diwawancara untuk mengetahui kebutuhan literasi pajak adalah bagian marketing PT ZAF Internasional yang memiliki jobdesk memasarkan produk-produk unggulan PT ZAF kepada klien.

Berikut ini adalah hasil temuan pelaksanaan penyuluhan pada tahap awal proses

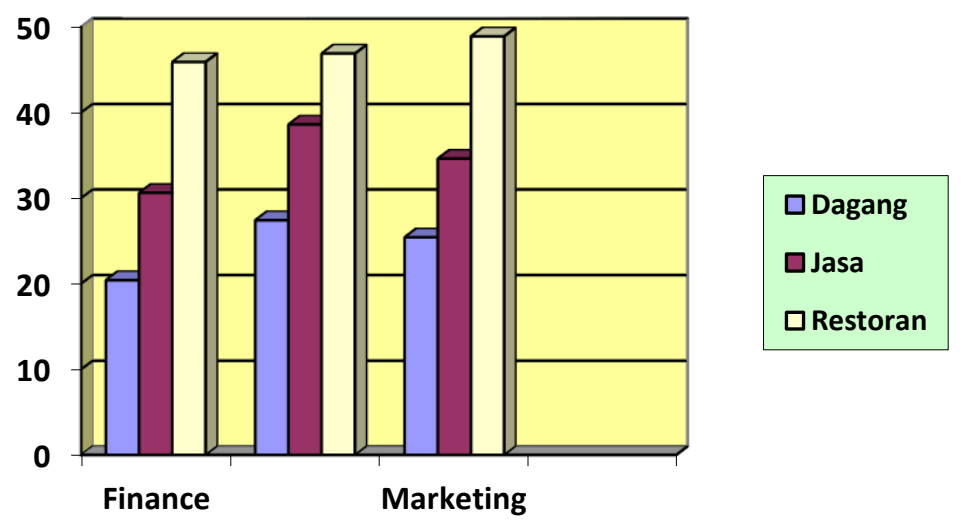

Gambar 3. Presentasi Pemilihan Tema Literasi Pajak UMKM

Berdasarkan hasil temuan di atas, tampak bahwa bagian finance, pajak, maupun marketing di PT ZAF Internasional memilih tema literasi pajak UMKM untuk restoran. Rata-rata setiap bagian di PT ZAF memilih restoran di atas $45 \%$ dengan rincian sebagai berikut:

1. Divisi Finance memilih tema literasi tentang pajak restoran sebanyak $45,9 \%$

2. Divisi Pajak memilih tema literasi tentang pajak restoran sebanyak $46,9 \%$

3. Divisi Marketing memilih tema literasi tentang pajak restoran sebanyak $48,9 \%$

Berdasarkan hasil wawancara setiap divisi memilih tema literasi pajak UMKM yang berbasis restoran dengan alasan sebagai berikut 
1. Sebagian besar klien PT ZAF adalah perusahaan jasa dan dagang sedangkan perusahaan berupa restoran masih jarang, sehingga literasi tentang pajak restoran dibutuhkan.

2. Metode pencatatan dan pembukuan akuntansi untuk pajak restoran lebih rumit dibandingkan untuk perusahaan jasa maupun perusahaan dagang.

3. Rekonsiliasi fiskal laporan keuangan dalam memilih deductable expense dan non-deductible expense dalam pelaporan pajak restoran lebih luas.

4. Peluang bisnis kuliner yang dilakukan oleh klien saat ini diprediksi akan berkembang pesat selain bisnis tekstil, jasa maupun perusahaan dagang.

5. Karakteristik manufaktur yang melekat pada restoran menjadi tantangan jika dibandingkan dengan jasa maupun dagang.

Capaian dalam kegiatan ini adalah kenaikan literasi pajak bagi mitra yang diwakili oleh PT ZAF Internasional, pada bagian awal proses penyuluhan mediasi dengan mitra hanya dilakukan dengan pengambilan data terkait dengan kebutuhan literasi pajak yang urgen digunakan oleh klien PT ZAF Internasional. Analisis ini menyimpulkan bahwa PPh untuk Pajak restoran menjadi fokus utama materi penyuluhan.

Berdasarkan hasil wawancara dan observasi yang dilakukan pada peserta pelatihan hasil evaluasi pengukuran capaian literasi pajak bagi mitra sebelum dan sesudah adanya penyuluhan digambarkan sebagai berikut:

Tabel 1. Hasil Evaluasi Pengukuran Capaian Literasi Pajak bagi Mitra

\begin{tabular}{|c|c|c|c|c|}
\hline No & $\begin{array}{c}\text { Indikator } \\
\text { Capaian }\end{array}$ & $\begin{array}{c}\text { Sebelum } \\
\text { Penyuluhan }\end{array}$ & $\begin{array}{c}\text { Setelah } \\
\text { Penyuluhan }\end{array}$ & Keterangan \\
\hline 1 & $\begin{array}{l}\text { Peserta } \\
\text { penyuluhan } \\
\text { memahami } \\
\text { NPWP } \\
\text { Pelaku } \\
\text { Usaha }\end{array}$ & $\begin{array}{l}\text { Peserta tidak bisa } \\
\text { membedakan } \\
\text { NPWP Orang } \\
\text { Pribadi dengan } \\
\text { NPWP Badan }\end{array}$ & $\begin{array}{l}\text { Peserta } \\
\text { memahami } \\
\text { dengan baik } \\
\text { NPWP Orang } \\
\text { Pribadi dengan } \\
\text { NPWP Badan }\end{array}$ & $\begin{array}{l}\text { Tercapai dan } \\
\text { terukur }\end{array}$ \\
\hline 2 & $\begin{array}{l}\text { Pencatatan } \\
\text { Transaksi } \\
\text { dan } \\
\text { Aktivitas } \\
\text { Harian }\end{array}$ & $\begin{array}{l}\text { Peserta tidak } \\
\text { memahami } \\
\text { pendekatan cash } \\
\text { basis dan accrual } \\
\text { basis dalam } \\
\text { melalukan } \\
\text { pencatatan } \\
\text { transaksi } \\
\text { perusahaan }\end{array}$ & $\begin{array}{l}\text { Peserta dapat } \\
\text { membedakan } \\
\text { dengan baik } \\
\text { pencatatan } \\
\text { transaksi dengan } \\
\text { dua pendekatan } \\
\text { yang berbeda } \\
\text { yaitu cash basis } \\
\text { dan accrual } \\
\text { basis }\end{array}$ & $\begin{array}{l}\text { Tercapai dan } \\
\text { terukur }\end{array}$ \\
\hline 3 & $\begin{array}{l}\text { Bentuk } \\
\text { Bisnis } \\
\text { Kuliner }\end{array}$ & $\begin{array}{l}\text { Peserta memahami } \\
\text { bentuk bisnis } \\
\text { kuliner hanya } \\
\text { dalam bentuk } \\
\text { konsep perusahaan } \\
\text { jasa }\end{array}$ & $\begin{array}{l}\text { Peserta sangat } \\
\text { baik memahami } \\
\text { bentuk bisnis } \\
\text { kuliner dalam } \\
\text { bentuk } \\
\text { perusahaan jasa } \\
\text { dan manufaktur } \\
\text { sehingga proses } \\
\text { perhitungan } \\
\text { harga pokok } \\
\text { produksi } \\
\text { makanan kuliner } \\
\text { mempertimbang }\end{array}$ & $\begin{array}{l}\text { Tercapai dan } \\
\text { terukur }\end{array}$ \\
\hline
\end{tabular}

KANGMAS is a journal published by Neolectura, issued three times in one year. KANGMAS is a scientific publication media in the form of conceptual paper and field research related to social service work. It is hoped that KANGMAS can become a media for academics and researchers to publish their social service work and become a reference source for the development of social and humanity.

Our focus: Social Service

Our Scope:

Humanities,

Education,

Management,

History,

Economics,

Linguistics,

Literature,

Religion,

Politics,

Sociology, Anthropology, and other social service works. 
KANGMAS: Karya Ilmiah Pengabdian Masyarakat, Vol. 2 No. 2, July 2021 - 70

http://journal.neolectura.com/index.php/kangmas

Vol. 2, No. 2,

July, 2021,

pp. $77-85$

e-ISSN:

2722-2004

Public

Communication

-Based Tax

Literacy

Counseling at

PT ZAF

Internasional

A. A. Utami,

K. Umam,

T. Djuhartono

\begin{tabular}{|c|c|c|c|c|}
\hline No & $\begin{array}{c}\text { Indikator } \\
\text { Capaian }\end{array}$ & $\begin{array}{c}\text { Sebelum } \\
\text { Penyuluhan }\end{array}$ & $\begin{array}{c}\text { Setelah } \\
\text { Penyuluhan }\end{array}$ & Keterangan \\
\hline 4 & $\begin{array}{l}\text { Pajak } \\
\text { Restoran }\end{array}$ & $\begin{array}{l}\text { Peserta tidak } \\
\text { memahami } \\
\text { hubungan antara } \\
\text { pajak restoran dan } \\
\text { pajak daerah }\end{array}$ & $\begin{array}{l}\text { kan overhead } \\
\text { pabrik yang } \\
\text { berimplikasi } \\
\text { pada pemilihan } \\
\text { metode } \\
\text { perhitungan HPP } \\
\text { dan nilai pajak } \\
\text { untuk produk } \\
\text { kuliner tersebut } \\
\text { Peserta } \\
\text { penyuluhan } \\
\text { memahami } \\
\text { dengan baik } \\
\text { konsep dan } \\
\text { ruang lingkup } \\
\text { pajak restoran } \\
\text { serta } \\
\text { hubungannya } \\
\text { dengan pajak } \\
\text { daerah }\end{array}$ & $\begin{array}{l}\text { Tercapai dan } \\
\text { terukur }\end{array}$ \\
\hline 5 & $\begin{array}{l}\text { PPh Final } \\
\text { UMKM }\end{array}$ & $\begin{array}{l}\text { Peserta } \\
\text { penyuluhan belum } \\
\text { bisa } \\
\text { mengidentifikasi } \\
\text { bahwa PPh final } \\
\text { UMKM tarifnya } \\
\text { berubah }\end{array}$ & $\begin{array}{l}\text { Peserta pelatihan } \\
\text { sangat baik } \\
\text { memahami tarif } \\
\text { terbaru untuk } \\
\text { PPh final } \\
\text { UMKM }\end{array}$ & $\begin{array}{l}\text { Tercapai dan } \\
\text { terukur }\end{array}$ \\
\hline 6 & $\begin{array}{l}\text { Pemotongan } \\
\text { PPh atas } \\
\text { transaksi } \\
\text { kepada } \\
\text { Pihak Lain }\end{array}$ & $\begin{array}{l}\text { Peserta } \\
\text { penyuluhan tidak } \\
\text { memahami } \\
\text { Pemotongan PPh } \\
\text { atas transaksi } \\
\text { kepada Pihak Lain }\end{array}$ & $\begin{array}{l}\text { Peserta pelatihan } \\
\text { memahami } \\
\text { dengan baik } \\
\text { Pemotongan PPh } \\
\text { atas transaksi } \\
\text { kepada Pihak } \\
\text { Lain }\end{array}$ & $\begin{array}{l}\text { Tercapai dan } \\
\text { terukur }\end{array}$ \\
\hline 7 & $\begin{array}{l}\text { Laporan } \\
\text { Keuangan } \\
\text { dan SPT } \\
\text { Tahunan } \\
\text { PPh }\end{array}$ & $\begin{array}{l}\text { Peserta } \\
\text { penyuluhan tidak } \\
\text { memahami proses } \\
\text { penyusunan } \\
\text { Laporan } \\
\text { Keuangan dan } \\
\text { SPT Tahunan PPh }\end{array}$ & $\begin{array}{l}\text { Peserta } \\
\text { penyuluhan } \\
\text { memahami } \\
\text { dengan baik } \\
\text { proses } \\
\text { penyusunan } \\
\text { Laporan } \\
\text { Keuangan dan } \\
\text { SPT Tahunan } \\
\text { PPh }\end{array}$ & $\begin{array}{l}\text { Tercapai dan } \\
\text { terukur }\end{array}$ \\
\hline 8 & $\begin{array}{l}\text { Pajak } \\
\text { Pertambahan } \\
\text { Nilai }\end{array}$ & $\begin{array}{l}\text { Peserta } \\
\text { penyuluhan tidak } \\
\text { memahami objek } \\
\text { Pajak } \\
\text { Pertambahan Nilai } \\
\text { untuk pajak } \\
\text { restoran }\end{array}$ & $\begin{array}{l}\text { Peserta } \\
\text { penyuluhan } \\
\text { memahami } \\
\text { dengan sangat } \\
\text { baik objek Pajak } \\
\text { Pertambahan } \\
\text { Nilai untuk pajak } \\
\text { restoran }\end{array}$ & $\begin{array}{l}\text { Tercapai dan } \\
\text { terukur }\end{array}$ \\
\hline
\end{tabular}


Kemampuan literasi pajak memiliki implikasi pada tingkat kepatuhan pajak (Sari 2019). Rahayu (2009) seperti dikutip oleh Ngadiman dan Huslin (2015) menyebutkan bahwa ada dua jenis klasifikasi kepatuhan pajak yaitu meliputi kepatuhan yang bersifat formal dan kepatuhan yang bersifat material. Literasi pajak mendukung kepatuhan pajak yang bersifat formal yaitu kepatuhan wajib pajak pada saat keadaan di mana wajib pajak dapat memenuhi kewajiban perpajakan secara formal dengan ketentuan yang ada di dalam undang-undang perpajakan. Urgensi penyuluhan literasi pajak ini berperan dalam mendukung tingkat kepatuhan wajib pajak untuk membayar pajak sesuai dengan jumlah yang harus dilaporkan. Berbeda dengan kepatuhan material yaitu suatu keadaan di mana wajib pajak secara substantif sudah memenuhi semua ketentuan material perpajakan, yakni sesuai isi dan jiwa undang-undang perpajakan, hal ini tidak dapat dicapai melalui peningkatan literasi pajak secara formal akan tetapi cukup dengan identifikasi ketentuan material wajib pajak secara subjektif.

\section{SIMPULAN}

Dari kegiatan workshop dan penyuluhan yang telah dilakukan oleh tim Abdimas lakukan dapat disimpulkan bahwa dengan menanamkan pendidikan mengenai pajak dan pengetahuan mengenai UMKM pada peserta dapat memunculkan self empowering dan kesadaran bagi setiap peserta. Pengetahuan dan kesadaran tentang pentingnya pajak harus selalu ditingkatkan Tidak cukup hanya kesadaran dan pengetahuan mengenai pajak, tapi juga peserta juga harus terampil dalam membuat laporan keuangan usahanya dan mengetahui cara-cara meng-input data keuangan untuk pajak. Hal ini sangat penting dalam rangka menciptakan wajib pajak yang cerdas dan mandiri.

\section{DAFTAR PUSTAKA}

Anggraeni, B. D. (2016). Pengaruh tingkat literasi keuangan pemilik usaha terhadap pengelolaan keuangan. Studi kasus: UMKM Depok. Jurnal Vokasi Indonesia, 4(1), 43-50. https://doi.org/10.7454/jvi.v4i1.50

Aribawa, D. (2016). Pengaruh Literasi Keuangan Terhadap Kinerja dan Keberlangsungan UMKM di Jawa Tengah. Jurnal Siasat Bisnis, 20(1), 1-13. https://doi.org/10.20885/jsb.vol20.iss1.art1

Mangoting, Y., \& Sadjiarto, A. (2013). Pengaruh Postur Motivasi Terhadap Kepatuhan Wajib Pajak Orang Pribadi. Jurnal Akuntansi Dan Keuangan, 15(2), 106-116. https://doi.org/10.9744/jak.15.2.106-116

Ngadiman, \& Huslin, D. (2015). Pengaruh Sunset Policy, Tax Amnesty, dan Sanksi 116 Pajak Terhadap Kepatuhan Wajib Pajak ( Studi Empiris di Kantor Pelayanan Pajak Pratama Jakarta Kembangan ). Jurnal Akuntansi, XIX(02), 225-241. https://doi.org/10.4018/978-1-5225-0651-5

Peraturan Pemerintah Republik Indonesia Nomor 23 Tahun 2018 Tentang Penghasilan Atas Penghasilan dari Usaha Yang Diterima Atau diperoleh Wajib Pajak Yang Memiliki Peredaran Bruto Tertentu, Pub. Lembaran Negara Republik Indonesia. Tahun 2018 Nomor 89, Peraturan Pemerintah 1 (2018). https://www.pajak.go.id/id/peraturanpemerintah-nomor-23-tahun-2018 
KANGMAS: Karya Ilmiah Pengabdian Masyarakat, Vol. 2 No. 2, July 2021 - 72

http://journal.neolectura.com/index.php/kangmas

Vol. 2, No. 2, July, 2021, pp. $77-85$

e-ISSN:

2722-2004

Sari, V. I. (2019). Pengaruh Literasi Pajak Dan Sanksi Pajak Terhadap Kepatuhan Wajib Pajak UMKM Di Kota Semarang Dengan Kesadaran Wajib Pajak Sebagai Variabel Moderating [Universitas Negeri Semarang]. http://lib.unnes.ac.id/id/eprint/35803

Yuliati, N. N., \& Fauzi, A. K. (2020). Literasi Pajak, Kualitas Pelayanan, Sanksi Perpajakan Dan Kepatuhan Wajib Pajak UMKM. Akutansi Bisnis \& Manajemen (ABM), 27(2), 26-44. https://doi.org/10.35606/jabm.v27i2.668

\section{Public}

Communication -Based Tax

\section{Literacy}

Counseling at

\section{PT ZAF}

Internasional

A. A. Utami, K. Umam,

T. Djuhartono 